\title{
METODE EDUKASI BRAINSTORMING DAN EDUKASI BUZZ GROUP TERHADAP PENINGKATAN SELF CARE PADA KLIEN CONGESTIVE HEART FAILURE
}

\author{
Eka Yudha Chrisanto ${ }^{1}$, Andoko $^{2 *}$, Cindy Desmonika ${ }^{3}$ \\ 1Dosen Program Studi Ilmu Keperawatan Universitas Malahayati \\ E-mail : yudhachrisanto88@gmail.com \\ ${ }^{2}$ Dosen Program Studi Ilmu Keperawatan Universitas Malahayati \\ E-mail : andoko2013@gmail.com \\ ${ }^{3}$ Mahasiswi Program Studi Ilmu Keperawatan Universitas Malahayati \\ E-mail : desmonikacindy22@gmail.com
}

\author{
Disubmit: 10 Agustus 2021 Diterima: 13 Agustus 2021 Diterbitkan: 01 Januari 2022 \\ DOI: https://doi.org/10.33024/mnj.v3i4.4791
}

\section{ABSTRACT: BRAINSTORMING EDUCATION AND BUZZ GROUP EDUCATION METHODS TO IMPROVING SELF CARE IN CONGESTIVE HEART FAILURE CLIENTS}

Introduction: Congestive heart failure is a serious disease, with the incidence and number of patients undergoing rehospitalization that continues to increase. This condition is caused by the lack of knowledge of clients and families about congestive heart failure and self care at home. Brainstorming education and Buzz group education can increase clients' understanding of Self Care.

Objective: This study aims to analyze the effectiveness of the Brainstorming educational method and the Buzz Group educational method on Self Care in patients with Congestive Heart Failure at Harapan Bunda Hospital in 2020.

Methods: This research is a Quasi Experiment research using a pretest and posttest design. The study population was clients who were treated at Harapan Bunda Hospital in 2020. The sample was taken using purposive sampling consisting of two groups, namely the brainstorming group of 15 respondents and the buzz group of 15 respondents.

Results: The results showed that there was a difference in the average value of increasing self-care before and after giving education using the brainstorming method with a difference in the mean value of 6.20 and the difference in increasing self-care before and after giving education using the buzz group method, which was 21.8. While the results of the analysis of differences in self care using the brainstorming and buzz group education methods with an average self-care value of 49.40 and 67.47, respectively, which means that the buzz group has a higher average value than the brainstorming group. The results of the independent $t$-test obtained a $p$-value of 0.000 .

Conclusion: The buzz group method is more effective in improving self-care in patients with Congestive Heart Failure compared to the brainstorming educational method. It is recommended that Harapan Bunda Hospital can use varied methods such as buzz groups in providing self-care education to Congestive Heart Failure patients.

Keywords : Brainstorming, Buzz Group, Self Care, Congestive Heart Failure 


\section{INTISARI: METODE EDUKASI BRAINSTORMING DAN EDUKASI BUZZ GROUP TERHADAP PENINGKATAN SELF CARE PADA KLIEN CONGESTIVE HEART FAILURE}

Pendahuluan: Congestive heart failure merupakan penyakit yang cukup serius, dengan angka kejadian dan jumlah pasien untuk mengalami rehospitalisasi yang terus meningkat.Kondisi ini dikarenkan minimnya pengetahuan klien dan keluarga tentang penyakit congestive heart failure dan self care di rumah. Edukasi brainstroming dan edukasi Buzz group dapat meningkatkan pemahaman Self Care klien.

Tujuan: Penelitian ini bertujuan untuk menganalisis efektifitas metode edukasi Brainstorming dan metode edukasi Buzz Group terhadap Self Care pada pasien penderita Congestive Heart Failure di Rumah Sakit Harapan Bunda Tahun 2020. Metode: Penelitian ini merupakan penelitian Quasi Experiment dengan menggunakan rancangan pretest and posttest design. Populasi penelitian adalah klien yang dirawat di Rumah Sakit Harapan Bunda pada Tahun 2020. Sampel diambil dengan menggunakan purposive sampling yang terdiri dari dua kelompok, yaitu kelompok brainstorming sebanyak 15 responden dan kelompok buzz group sebanyak 15 responden.

Hasil: Hasil penelitian menunjukan terdapat perbedaan nilai rata-rata peningkatan self care sebelum dan sesudah pemberian edukasi menggunakan metode brainstorming dengan selisih nilai mean 6,20 dan perbedaan peningkatan self care sebelum dan sesudah pemberian edukasi menggunakan metode buzz group yaitu 21,8. Sedangkan hasil analisis perbedaan self care menggunakan metode edukasi brainstorming dan buzz group dengan nilai ratarata self care masing-masing 49,40 dan 67,47 yang artinya pada kelompok buzz group memiliki nilai rata-rata lebih tinggi dibandingkan kelompok brainstorming. Hasil uji t-tes independen didapat nilai $p$-value 0,000 .

Kesimpulan: Metode buzz group lebih efektif dalam peningkatan self care pada pasien penderita Congestive Heart Failure dibandingkan dengan metode edukasi brainstorming.

Kata Kunci : Congestive Heart Failure, Brainstorming, Buzz Group, Self Care

\section{PENDAHULUAN}

Gagal jantung merupakan kumpulan gejala yang kompleks ditandai oleh berkurangnya kemampuan jantung untuk memompa darah sehingga output yang dihasilkan jantung tidak adekuat untuk memenuhi kebutuhan metabolic (Laksmi, 2019; Nadya, 2020). Heart failure adalah ketidakmampuan jantung dalam memenuhi kebutuhan oksigen dan nutrisi jaringan tubuh yang disebabkan oleh kegagalan jantung dalam memompakan darah. Hipertensi kronis, Coronary Artey Disease (CAD) dan valvular disease merupakan kondisi kardiovaskuler yang menyebabkan Kegagalan fungsi pompa jantung (Smaltzer, Bare, Hinkle, \& Cheeer, 2010 dalam Kaawoan, 2012).

Data dari World Helath Organization (WHO) menunjukkan bahwa 41 juta orang meninggal setiap tahun. Sebesar 17.9 juta dari total kematian tersebut disebabkan oleh penyakit kardiovaskuler (WHO, 2018).Kemenkes RI (2017) menyatakan bahwa di Indonesia angka kematian tertinggi disebabkan oleh Penyakit Jantung dengan persentase $12.9 \%$. Berdasarkan data Riskesdas tahun 
2018, prevalensi gagal jantung berdasarkan diagnosis dokter di Indonesia sebesar 1,8\% dan jumlah ini jauh meningkat dari tahun sebelumya. Peningkatan prevalensi ini seiring dengan bertambahnya umur, pada umur 65-74 tahun $(4,6 \%)$, meningkat pada umur $\leq 75$ tahun $(4,7 \%)$ dan prevalensi pada perempuan $(1,6 \%)$ lebih tinggi dibanding laki-laki (1,3\%). Sedangkan berdasarkan diagnosis dokter di Provinsi Lampung, sebanyak $1.2 \%$ (Riskesdas, 2018).

Penanganan congestive heart failure terdiri dari : (1) penanganan umum tanpa obat-obatan, menggunakan obat-obatan menggunakan alat dan tindakan bedah. Penanganan congestive heart failure ini bertujuan untuk memperbaiki pompa ventrikel, mengurangi beban miokardium, perfusi organ esensial, mencegah congestive heart failure berkelanjutan dengan melakukan perbaikan gaya hidup (Chrisanto, 2018).

Menurut penelitian yang dilakukan Kaawoan (2012) self care congestive heart failure memberikan dampak yang positif dalam memenuhi kebutuhan dasar klien, seperti penurunan citra tubuh, penurunan perilaku dan aktivitas sehari-hari, kelelahan kronis, disfungsi seksual, kekhawatiran tentang masa depan dan kurangnya perawatan diri. Self care adalah perawatan diri, yang mengacu pada tindakan yang diambil oleh seseorang untuk meningkatkan dan mempertahankan kehidupan, kesehatan dan kesejahteraan. Ini dikonseptualisasikan sebagai bentuk yang disengaja dan mengacu pada tindakan yang diambil secara sadar oleh individu (Chrisanto, 2018).

Manajemen perawatan diri itu seperti: manajemen obat, diet, aktifitas fisik, pembatasan cairan dan aktifitas psikososial, jika manajemen perawatan diri tidak baik maka akan mempengaruhi tingkat kekambuhan gagal jantung. (Anggraheni, 2019). Menurut Smaltzer (2010) dalam Chrisanto (2018), Sebagian besar pasien Congestive Heart Failure yang masuk kembali ke rumah sakit karena kambuh sering tidak mengikuti metode pengobatan yang direkomendasikan, seperti ketidakmampuan untuk menerima pengobatan yang tepat, pelanggaran pembatasan diet, ketidakpatuhan terhadap tindak lanjut medis, aktivitas fisik yang berlebihan., dan ketidakmampuan untuk mengenali gejala kekambuhan. Faktor ketidakmauan, ketidakmampuan dan ketidaktahuan tentang penyakit dan perawatan diri (self care) yang menyababkan berkurangnya self care klien congestive heart failure dapat terjadi.

Berdasarkan hal tersebut dapat ditekankan bahwa penting untuk mengedukasi pasien dan keluarga tentang Congestive Heart Failure dan perawatan diri. Memberikan edukasi kepada klien dan keluarga merupakan tanggung jawab utama perawat. (Bastable, 2006 dalam Chrisanto, 2018). Peran perawat menurut Konsorsium Ilmu Kesehatan Tahun 1989 adalah sebagai pemberi asuhan keperawatan, advokat pasien, pendidik/edukator, koordinator, kolaborator, konsultan dan sebagai peneliti (Budiono, 2015). Karenanya, edukasi merupakan management umum tanpa pengobatan pada congestive heart failure. Standar pendidikan klien dari institusi pelayanan keperawatan mengharuskan perawat dan tim kesehatan untuk memberikan pendidikan tentang berbagai topik seperti pengobatan, 
nutrisi, penggunaan alat kesehatan, nyeri, dan rencana perawatan klien. Pekerjaan pendidikan harus mencakup psikologi sosial klien, nilai-nilai spiritual dan budaya, dan keinginan untuk berpartisipasi aktif( Chrisanto, 2018).

Edukasi merupakan standar praktik keperawatan professional, dalam pemberian pendidikan harus mencakup nilai psikososial, spiritual dan budaya yang dimiliki serta keinginan untuk berparisipasi aktif. Pemberian edukasi dapat dilakukan melalui berbagai metode diantaranya diskusi, ceramah, peragaan, metode cetakan/ leaflet, permainan, alat bantu audiovisual (AVA), contoh kasus dan latihanlatihan afektif, role play, komputer, buzz group serta metode brainstorming (Notoatmodjo, 2007 dalam Noeraini, 2019). Brainstorming merupakan metode pendidikan yang dimodifikasi dari metode diskusi kelompok. Prinsipnya sama dengan metode diskusi kelompok. Bedanya pada pada awalnya, ketua kelompok memancing dengan satu masalah kemudian masing-masing peserta memberikan jawaban dan jawaban tersebut ditampung dan didiskusikan (Bolin, 2006 dalam Noeraini, 2019). Dalam penelitian Chrisanto (2018) dijelaskan bahwa brainstorming merupakan metode pemecahan masalah, metode ini telah digunakan dalam dunia pendidikan, ilmu teknik dan keperawatan .

Metode brainstorming

diharapkan dapat menciptakan suasana edukasi yang lebih menyenangkan, sehingga dapat meningkatkan minat tentang self care congestive heart failure. Kajian ini menunjukan bahwa edukasi yang diberikan oleh tenaga kesehatan sangat penting bagi klien congestive heart failure untuk melakukan perawatan diri (self care). Hal ini selaras dengan penelitian yang dilakukan oleh Chrisanto (2018) yang menyatakan bahwa terdapat pengaruh metode edukasi brainstroming terhadap self care pada klien congestive heart failure. Penggunaan medote edukasi braistorming diharapkan meningkatkan pemahaman dan motivasi klien congestive heart failure yang menghasilkan perubahan prilaku untuk melaksanakan self care secara berkelanjutan (Chrisanto, 2018).

Beberapa penelitian pun ditemukan kasus yang sama dalam penerapan metode brainstorming terhadap penanganan penyakit. Penelitian Hardita, Qur aniati, Kristiawati (2015) ditemukan bahwa ada pengaruh pendidikan kesehatan brainstorming pencegahan ISPA terhadap pengetahuan dan sikap ibu dengan anak toodler di desa Kedunglosari Tembelan Jombang. Selain itu, penelitian Winancy, Raksanagara \& Fuadah (2015) menunjukkan bahwa metode pendidikan kesehatan brainstorming dan buzz group memiliki pengaruh terhadap peningkatan pengetahuan suami ibu hamil tentang tanda bahaya kehamilan, persalinan, dan nifas.

Metode buzz group digunakan dalam kegiatan pembelajaran untuk memecahkan suatu masalah. Metode diskusi buzz group adalah salah satu bentuk diskusi kelompok yang beranggotakan 4-5 orang yang bertemu secara bersama-sama membicarakan suatu topik yang sebelumnya telah dibahas secara klasikal" (Helmi, 2019; Rohimah, 2020).

Keuntungan dari Buzz Group Discussion yaitu membantu peserta didik untuk bisa menyampaikan gagasan atau pendapat di dalam kelompok, menumbuhkan suasana 
akrab dan menyenangkan, mendorong tiap anggota untuk berpartisipasi dalam diskusi (Ikromah, 2015).

Beberapa penelitian juga ditemukan kasus yang sama dalam penerapan metode buzz group terhadap suatu masalah. Penelitian Ikromah, Asmaningrum, Sulistiyorini (2015) ditemukan ada perbedaan metode buzz group discussion dengan ceramah audiovisual terhadap tingkat pendidikan warga binaan tentang hiv/aids di lembaga pemasyarakatan klasiia kabupaten jember. Selain itu penelitian Helmi (2019) juga menunjukan bahwa metode pembelajaran buzz group berpengaruh terhadap hasil belajar siswa.

\section{METODE PENELITIAN}

Penelitian ini merupakan penelitian kuantitatif dengan desain penelitian Quasi Eksperimental menggunakan rancangan "pre test and post test design". Populasi dalam penelitian ini adalah seluruh pasien Congestive Heart Failure di Poli Jantung Rumah Sakit Harapan Bunda. Teknik pengambilan sampel dalam penelitian ini menggunakan metode non probability sampling dengan pendekatan purposive sampling. Besar sampel dalam penelitian ini untuk dua kelompok sebanyak 30 orang. Penelitian ini telah dilakukan Tanggal 25-30 November 2020 di Poli Klinik Jantung Rumah Sakit Harapan Bunda Lampung Tengah. Penelitian ini dinyatakan lolos kaji etik oleh Komisi Etik Penelitian Kesehatan Fakultas Kedokteran Univeristas Malahayati dengan nomor sertifikat 1268/EC/KEP-UNMAL/IX/2020. Alat ukur/ Instrumen berupa kuesioner (angket tertutup) dengan jumlah pertanyaan 20 item pertanyaan yang terdiri dari 8 item pertanyaan untuk dimensi self care maintenance, 6 item pertanyaan self care management, dan 6 item pertanyaan self care confidence dengan penilaian menggunakan skala Likert. Peneliti menggunakan kuesioner yang sudah pernah dilakukan uji validitas dan reliabilitas, sehingga peneliti tidak melakukan uji validitas dan reliabilitas lagi. Instrumen yang digunakan merupakan instrumen dari penelitian: Adeleida Yuliana Anita Kawooan (2012) Hubungan Self Care Dan Depresi Dengan Kualitas Hidup Pasien Heart Failure Di RSUP Prof.DR.R.D Kandou Manado, dengan nilai uji $r \geq 0,3$ Analisis data univariat dan bivariat (uji t-test dependen) dengan menggunakan aplikasi IBM SPSS Statistik.

HASIL

Karakteristik Responden

Tabel 1

Distribusi Frekuensi Karakteristik Responden.Berdasarkan Usia Jenis Kelamin Dan Pendidikan Pada Pasien Congestive Heart Failure Di Rumah Sakit Harapan Bunda Tahun 2020

\begin{tabular}{cclcl}
\hline & & $\begin{array}{l}\text { Edukasi } \\
\text { Brainstorming }\end{array}$ & & $\begin{array}{l}\text { Edukasi } \\
\text { Buzz Group }\end{array}$ \\
\hline Usia & f & Persentase (\%) & f & Persentase (\%) \\
\hline$<50$ Tahun & 9 & 60,0 & 8 & 53,3 \\
$\geq 50$ Tahun & 6 & 40,0 & 7 & 46,7 \\
\hline Jenis Kelamin & f & Persentase (\%) & f & Persentase (\%) \\
\hline
\end{tabular}




\begin{tabular}{cllll}
\hline Laki-laki & 8 & 53,3 & 9 & 60,0 \\
Perempuan & 7 & 46,7 & 6 & 40,0 \\
\hline Pendidikan & $\mathbf{f}$ & Persentase (\%) & $\mathbf{f}$ & Persentase (\%) \\
\hline SD & 2 & 13,3 & - & - \\
SMP & 4 & 40,0 & 2 & 13,3 \\
SMA & 6 & 26,7 & 10 & 66,7 \\
D3 & 1 & 6,7 & 1 & 6,7 \\
S1 & 2 & 13,3 & 2 & 13,3 \\
\hline Total & $\mathbf{1 5}$ & 100 & $\mathbf{1 5}$ & 100 \\
\hline
\end{tabular}

Berdasarkan tabel 1 di atas dapat dijelaskan bahwa rata-rata usia responden adalah usia $<50$ tahun sebanyak 9 responden $(60,0 \%)$ pada kelompok brainstorming, 8 responden $(53,3 \%)$ pada kelompok buzz group, dan jenis kelamin terbanyak adalah laki-laki sebanyak 8 responden $(53,3 \%)$ pada kelompok

\section{Analisis Univariat}

Tabel 2 Rata-rata Self Care Sebelum dan Sesudah Dilakukan.Edukasi Brainstorming Pada Pasien Congestive Heart Failure Di Rumah Sakit Harapan Bunda Tahun 2020

\begin{tabular}{lcclll}
\hline Self Care & $\mathrm{n}$ & Mean & SD & Min-Max & Cl; 95\% \\
\hline Pretest & 15 & 43,20 & 3,550 & $36-51$ & $41,23-45,17$ \\
\hline Postest & 15 & 49,40 & 6,139 & $37-58$ & $46,00-52,8$ \\
\hline
\end{tabular}

Berdasarkan tabel 2 di atas, dapat dijelaskan bahwa sebelum (pretest) perlakuan edukasi brainstorming rata-rata self care 15 responden dengan mean 43,20 dengan nilai terendah 36 dan nilai brainstorming, 9 responden $(60,0 \%)$ pada kelompok buzz group, pendidikan terbanyak adalah kategori SMA 6 responden $(40,0 \%)$ pada kelompok brainstorming dan 10 responden $(66,7 \%)$ pada kelompok buzz group . tertinggi 51. Sedangkan sesudah (posttes) perlakuan edukasi brainstorming rata-rata self care 15 responden dengan mean 49,40 dengan nilai terendah 37 dan nilai tertinggi 58.

Tabel 3 Rata-rata Self Care Sebelum dan Sesudah Dilakukan.Edukasi Buzz Group Pada Pasien Congestive Heart Failure Di Rumah Sakit Harapan Bunda Tahun 2020

\begin{tabular}{cccccc}
\hline Self Care & $\mathrm{N}$ & Mean & SD & Min-Max & Cl; 95\% \\
\hline Pretest & 15 & 45,67 & 6,289 & $36-58$ & $42,18-49,15$ \\
\hline Postest & 15 & 67,47 & 5,975 & $56-78$ & $64,16-70,78$ \\
\hline
\end{tabular}

Berdasarkan tabel 3 di atas, dapat dijelaskan bahwa sebelum (pre-test) perlakuanedukasi buzz group rata-rata self care 15 responden dengan mean 45,67 dengan nilai terendah 36 dan nilai tertinggi 58. Sedangkan sesudah

(posttes) perlakuan edukasi buzz group rata-rata self care 15 responden dengan mean 67,47 dengan nilai terendah 56 dan nilai tertinggi 78. 
Tabel 4

Perbandingan Metode Edukasi Brainstorming Dan...Metode Edukasi Buzz Group Terhadap Self Care.Pada Pasien.Congestive Heart Failure Di Rumah Sakit Harapan Bunda Tahun 2020

\begin{tabular}{llccc}
\hline Self Care & Mean \pm SD & $T$ & $P$-value & $95 \% \mathrm{Cl}$ \\
\hline Pretest & $49,40 \pm 6,139$ & & & \\
Postest & $67,47 \pm 5,975$ & $-8,168$ & 0,000 & $-22,597-13,536$ \\
\hline
\end{tabular}

Berdasarkan tabel 4 di atas dapat diketahui bahwa pada hasil analisis diperoleh rata-rata self care pada 15 responden pada masing-masing kelompok edukasi brainstorming dan edukasi buzz group dengan nilai mean masing-masing 49,40 dan 67,47 yang artinya pada kelompok buzz group memiliki nilai rata-rata lebih tinggi dibandingkan kelompok brainstorming.

\section{PEMBAHASAN}

\section{Karakteristik Responden}

Berdasarkan tabel 1 di atas dapat dijelaskan bahwa rata-rata usia responden adalah usia $<50$ tahun sebanyak 9 responden $(60,0 \%)$ pada kelompok brainstorming, 8 responden $(53,3 \%)$ pada kelompok buzz group, dan jenis kelamin terbanyak adalah laki-laki sebanyak 8 responden $(53,3 \%)$ pada kelompok brainstorming, 9 responden $(60,0 \%)$ pada kelompok buzz group, pendidikan terbanyak adalah kategori SMA 6 responden $(40,0 \%)$ pada kelompok brainstorming dan 10 responden $(66,7 \%)$ pada kelompok buzz group .

Dari hasil penelitian diatas diketahui bahwa responden laki laki memiliki jumlah terbanyak. Hal ini berarti bahwa penyakit gagal jantung lebih banyak diderita oleh laki laki. Hasil penelitian ini sesuai dengan penelitian yang telah dilakukan oleh Anggraheni (2019) yang menyatakan bahwa resiko gagal jantung dapat dipengaruhi oleh jenis kelamin. Hal tersebut
Hasil analisa data bivariat menggunakan uji $t$-tes independen didapat nilai $p$-value $0,000<0,05$ maka dapat ditarik kesimpulan terdapat perbandingan metode edukasi braistorming dan. Metode edukasi buzz group terhadap self care pada pasien. Congestive Heart Failure di Rumah Sakit Harapan Bunda tahun 2020.

disebabkan karena laki-laki tidak memiliki hormon esterogen yang berguna untuk melindung tubuh dari penyakit degenerative sehingga laki-laki berpeluang lebih besar untuk terkena penyakit gagal jantung.

$\begin{array}{lr}\text { Berdasarkan } & \text { penelitian } \\ \text { diatas didapatkan } & \text { bahwa } \\ \text { karakteristik usia rata rata }\end{array}$
responden yaitu $<50$ tahun. Hal ini sesuai dengan penelitian yang telah dilakukan oleh Febtrina (2017) di RSUD Arifin Achmad Pekanbaru yang menemukan jika sebagian besar responden penderita gagal jantung memasuki usia lanjut. Hasil Riskesdas (2018) juga menyebutkan prevalensi gagal jantung meningkat seiring bertambahnya umur terutama terjadi pada usia lanjut . Hal ini disebabkan karena orang dengan usia lanjut memiliki ukuran jantung cenderung lebih besar, penebalan pembuluh darah arteri dan elastisitas jaringan berkurang (Anggraheni, 2019).

$$
\text { Berdasarkan penelitian }
$$

diatas didapatkan bahwa rata-rata 
reponden berpendidikan rendah. Hasil penelitian ini sesuai dengan penelitian yang telah dilakukan oleh Kaawoan (2012) kemampuan Self Care pasien Congestive Heart Failure berhubungan dengan tingkat pendidikan yaitu pasien dengan tingkat pendidikan yang tinggi memiliki hubungan dengan kemampuan Self Care yang baik dan kepatuhan dalam pengobatan. Tingkat pendidikan sangat menentukan kemampuan pasien dalam memahami kondisi kesehatanya. Individu dengan tingkat pendidikan yang rendah akan mengalami kesulitan dalam mengenali masalah kesehatan dan memahami cara penanganan penyakit dibandingkan dengan individu yang memiliki tingkat pendidikan yang tinggi. Kemampuan individu yang baik tersebut akan meningkatkan pengenalan pasien terhadap faktor yang mempengaruhi kesehatanya dan dampak pendidikan juga berpengaruh terhadap kepatuhan seseorang dalam menjalankan pengobatanya (Chrisanto, 2018).

\section{Analisis Univariat}

Self Care Sebelum Dan Sesudah Dilakukan Edukasi Brainstorming Pada Pasien Congestive Heart Failure Di Rumah Sakit Harapan Bunda Tahun 2020.

Pada table diatas menunjukkan mean sebelum edukasi 43,20 dan setelah diberi edukasi menjadi 49,50 .

Sejalan dengan penelitian yang dilakukan oleh Deny Martha Hardita (2015) dengan judul "Brainstorming Dalam Pencegahan Infeksi Saluran Pernapasan Akut (Ispa) Oleh Ibu" Data yang diperoleh dianalisis dengan menggunakan teknik statistik Wilcoxon Signed Rank.
Hasil penelitian ini menunjukkan bahwa ada peningkatan pengetahuan dalam pencegahan ISPA pada anak toodler sebelum dan sesudah intervensi. Setelah diberikan intervensi, pengetahuan meningkat meningkat menjadi 15 responden $(78,9 \%)$ baik dan 4 responden $(21,1 \%)$ berpengetahuan cukup.

Pendidikan ialah segala upaya yang digunakan untuk mempengaruhi orang lain, baik individu, kelompok atau masyarakat, sehingga mereka dapat melakukan apa yang di harapkan oleh pendidik (Nofalia, 2018). Menurut Notoatmodjo (2003) dalam Nofalia (2018) pendidikan kesehatan adalah proses peningkatan kemampuan masyarakat untuk memelihara dan meningkatkan kesehatan. Pendidikan kesehatan merupakan kegiatan keperawatan mandiri yang digunakan untuk membantu klien (termasuk individu, kelompok,dan masyarakat) dalam mengatasi masalah kesehatannya melalui kegiatan pembelajaran, dimana perawat berperan sebagai pendidik.

Berdasarkan uraian hasil penelitian di atas dapat dijelaskan bahwa setelah diberikan edukasi brainstorming, self care responden mengalami peningkatan. Hal ini menunjukan jika manfaat edukasi sangatlah besar dalam mengubah paradigma, pemahaman, sikap serta perubahan perilaku yang berdampak pada perilaku self care yang lebih baik lagi.

Self Care Sebelum Dan Sesudah Dilakukan Edukasi Buzz Group Pada Pasien Congestive Heart Failure Di Rumah Sakit Harapan Bunda Tahun 2020.

Pada table diatas menunjukkan mean sebelum 
edukasi 45,67 dan setelah diberi edukasi menjadi 67,47.

Sejalan dengan penelitian yang dilakukan oleh Daslinar (2019) Pengaruh Metode Pembelajaran Buzz Group Pada Materi Kelarutan Dan Hasil Kali Kelarutan (Ksp) Terhadap Hasil Belajar Siswa di Mas Idi Cut Aceh Timur. Didapatkan hasil angket respon siswa yaitu 94\% yang dapat disimpulkan siswa sangat tertarik menggunakan metode buzz group. Hasil belajar siswa yang dibelajarkan menggunakan metode buzz group diperoleh nilai rata-rata 47,00 sedangkan dengan metode konvensional diperoleh nilai ratarata 44,33 .

Sikap dan perilaku merupakan bagian dari budaya. Kebiasaan, adat istiadat, tata nilai atau norma termasuk dalam budaya. Tidak mudah untuk mengubah kebiasaan, adat dan kepercayaan yang sudah menjadi norma atau nilai social. Itu harus melewati proses panjang karena kebudaya adalah sikap, perilaku dan cara berpikir yang dihasilkan orang dalam proses belajar (Novalia, 2011).

Hasil dalam penelitian ini terdapat perubahan skor self care setelah diberikan edukasi buzz group dengan skor nilai sebelum mean 45,67 dan setelah diberi intervensi mean 67,47 yang artinya edukasi buzz group sangat membantu responden dalam meningkatkan self care mereka.

Peneliti berasumsi bahwa self care berdampak besar dalam meningatkan kualitas hidup seseorang, Bila perawatan diri seseorang baik maka kualitas hidupnya pasti akan baik, begitu pula sebaliknya, kualitas hidup merupakan suatu pandangan individu dalam hidup, Dari perspektif sistem, nilai-nilai yang mereka jalani terkait dengan standar hidup, harapan, kebahagiaan, dan perhatian mereka. Ini termasuk kesehatan fisik, keadaan mental, derajat kebebasan, hubungan sosial, dan hubungan dengan lingkungan.

\section{Analisis Bivariat}

Perbandingan Metode Edukasi Braistorming Dan Metode Edukasi Buzz Group Terhadap Selfcare Pada Pasien Congestive Heart Failure Di Rumah Sakit Harapan Bunda Tahun 2020.

Hasil analisa data bivariat menggunakan uji $t$-tes independen didapat nilai $p$-value $0,000<0,05$ maka dapat ditarik kesimpulan terdapat perbandingan metode edukasi braistorming dan metode edukasi buzz group terhadap selfcare pada pasien congestive heart failure di Rumah Sakit Harapan Bunda tahun 2020.

Hasil penelitian ini sejalan dengan penelitian yang dilakukan Eka Yudha Chrisanto (2018) dengan judul "Pengaruh Metode Edukasi Brainstorming Terhadap Self Care Pada Klien Congestive Heart Failure" didapatkan hasil dengan Uji statistik dilakukan dengan dependen t-test. sehingga dihasilkan nilai $p<0.05$. Hasil penelitian diketahui bahwa terdapat perbedaan yang signifikan rata-rata self care kelompok intervensi setelah dilakukan metode edukasi brainstorming dengan $(p=0,000)$ serta tidak terdapat hubungan antara jenis kelamin $(p=0,095)$ dan tingkat pendidikan $(p=0,726)$ dengan self care. Sedangkan setelah dilakukan metode edukasi brainstorming dan dikontrol oleh usia $(0,016)$ self care menjadi meningkat. 
2013 Menurut Effendi \& Makhfudli Brainstorming juga sering disebut dengan curah pendapat. Moderator memimpin dengan mengajukan pertanyaan atau permasalahan, kemudian peserta memberikan jawaban dan tanggapan. Jawaban akan ditulis pada flipchart atau papan tulis oleh notulen. Brainstorming dilakukan tanpa adanya pendapat atau saran dari siapapun. Setelah semua peserta menyampaikan pendapat masingmasing, langkah selanjutnya adalah memberikan komentar dan diskusi.

Metode diskusi buzz group adalah salah satu bentuk diskusi kelompok yang beranggotakan 4-5 orang yang bertemu secara bersama-sama membicarakan suatu topik yang sebelumnya telah dibahas secara klasikal" (Dimyati\&moedjiono, 1999 dalam Helmi, 2019).

Hasil analisis diperoleh ratarata self care pada 15 responden pada masing-masing kelompok edukasi brainstorming dan edukasi buzz group dengan nilai mean masing-masing 49,40 dan 67,47 yang artinya pada kelompok buzz group memiliki nilai rata-rata lebih tinggi dibandingkan kelompok brainstorming.

Menurut peneliti, Metode brainstorming (curah pendapat) ini sama dengan metode diskusi kelompok namun pada metode brainstorming, pemimpin kelompok mengajukan permasalahan kemudian peserta memberikan jawaban atau tanggapan. Tanggapan atau jawaban tersebut ditampung dan ditulis dalam flipchart atau papan tulis (Azki, 2019). Sebelum semua peserta mengungkapkan pendapatnya, tidak boleh diberi sanggahan oleh siapapun. Setelah semua anggota mengungkapkan pendapatnya maka tiap anggota dipersilakan untuk memberikan sanggahanya sehingga terjadilah diskusi (Hapsari, 2011). Metode diskusi buzz group merupakan alat untuk membagi kelompok diskusi kelompok besar kelompok menjadi kecil. Teknik yang digunakan adalah dengan membagi kelompok menjadi kelompok-kelompok kecil. Beberapa kelompok terdiri dari 10 sampai 15 orang, jika kelompok asalnya berjumlah 30 orang atau lebih. Sekretaris mencatat, memuat ideide yang disarankan oleh anggota dan menyiapkan kesimpulan yang akan disampaikan kepada kelompok besar setelah diskusi dikelompok kecil selesai. Kemudian sekretaris tiap kelompok, diminta untuk melaporkan hasil diskusi sebelum dibuka diskusi kelompok umum. Waktu yang diperlukan untuk diskusi Buzz group berkisar 10-20 menit tergantung pada topik yang dibicarakan (Ruwayda, 2021).

\section{Kesimpulan}

Rata-rata usia responden adalah usia < 50 tahun sebanyak 9 responden $(60,0 \%)$ pada kelompok brainstorming, 8 responden $(53,3 \%)$ pada kelompok buzz group, dan jenis kelamin terbanyak adalah lakilaki sebanyak 8 responden $(53,3 \%)$ pada kelompok brainstorming, 9 responden $(60,0 \%)$ pada kelompok buzz group, pendidikan terbanyak adalah kategori SMA 6 responden (40,0\%) pada kelompok brainstorming dan 10 responden $(66,7 \%)$ pada kelompok buzz group.

Rata-rata self care 15 responden sebelum edukasi brainstorming dengan mean 43,20. Rata-rata self care 15 responden sesudah edukasi brainstorming dengan mean 49,40. Rata-rata self care 15 responden sebelum edukasi buzz group dengan mean 45,67. Rata-rata 
self care 15 responden sesudah edukasi buzz group dengan mean 67,47. Hasil analisa data bivariat menggunakan uji t-tes independen didapat nilai $p$-value $0,000<0,05$ maka dapat ditarik kesimpulan terdapat perbandingan metode edukasi braistorming dan metode edukasi buzz group terhadap self care pada pasien congestive heart failure di Rumah Sakit Harapan Bunda Tahun 2020.

\section{Saran}

$\begin{array}{lcr}\quad \text { Bagi } & \text { institusi } & \text { pendidikan } \\ \text { khususnya } & \text { prodi } & \text { Keperawatan } \\ \text { Universitas } & \text { Malahayati } & \text { Bandar } \\ \text { Lampung } & \text { diharapkan } & \text { untuk }\end{array}$ meningkatkan pendidikan dibidang keperawatan komplementer terkait metode edukasi yang tepat bagi responden dengan gagal jantung guna peningkatan self care. Bagi institusi pelayanan kesehatan diharapkan agar dapat melakukan edukasi kesehatan buzz group secara terstruktur dan dibentuk suatu protap (SOP) khusus agar dalam perawatan dan pengobatan terjadi perubahan self care yang lebih baik terhadap pasien gagal jantung.Bagi responden edukasi dengan berbagai metode ini hendaknya menjadi bagian integral program rehabilitasi pasien gagal jantung setelah pulang dari rumah sakit sehingga hasilnya lebih baik dan dapat diwujudkan menjadi aktifitas kesukaan pasien. Bagi penelitian lain yang ingin melakukan penelitian yang berhubungan dengan upaya meningkatkan self care pasien gagal jantung dengan edukasi yang bersifat merubah perilaku dan dapat memberikan rehabilitasi pada klien gagal jantung.

\section{DAFTAR PUSTAKA}

Anggraheni, A. A. (2019). Gambaran Self Care Behaviour Pada Pasien Gagal Jantung. Skripsi, Universitas Muhammadiyah Surakarta.

Azki, F. F., \& Rokhaidah, R. (2019). Pendidikan Kesehatan Dengan Metode Brainstorming Dan Media Audiovisual Berpengaruh Terhadap Pengetahuan Ibu Tentang Pencegahan Difteri. Jurnal Keperawatan Widya Gantari Indonesia, 3(2), 1-6.

Budiono, Pertami, S. B. (2015). Konsep Dasar Keperawatan. Jakarta: Bumi Medika.

Chrisanto, E. Y., Astuti, W. (2018). Pengaruh Metode Edukasi Brainstorming Terhadap Self Care Pada Klien Congestive Heart Failure. Holistik Jurnal Kesehatan, 12(4).

Djamaludin, D., Tua, R.., Deria, D. (2018). Hubungan Pengetahuan Dan Self Care Dengan Kualitas Hidup Pasien Gagal Jantung di RSUD Dr.H.Abdul Moloek Provinsi Lampung. Holistik Jurnal Kesehatan, 12(3).

Diantami, A. Y. M. (2017). Pengaruh Metode Brainstorming Terhadap Tingkat Pengetahuan Dan Rasionalitas Penggunaan Obat Swamedikasi. Skripsi, Universitas Airlangga.

Hapsari, M. R. (2011). Pengaruh Penerapan Metode Brainstorming Disertai Pemutaran Video Terhadap Peningkatan Pengetahuan Tentang Gangguan Akibat Kekurangan lodium Pada Siswa Kelas $V$ SDN Gunungwungkal Kecamata nGunungwungkal Kabupaten Pati. Skripsi, Universitas Negeri Semarang.

Hardita, D. M., Qur'aniati, N., Kristiawati. (2015). Brainstorming Dalam Pencegahan 
Infeksi Saluran Pernapasan Akut (ISPA) Oleh Ibu (Studi Kasus di Jombang). Jurnal Pediomaternal, 3(1).

Helmi, A., Baysha, M. H. (2019). Pengaruh Metode Pembelajaran Buzz Group Terhadap Hasil Belajar Siswa(Studi Kasus Di Lombok). Jurnal Teknologi Pendidikan, 4(1).

Ikromah, J. N., Asmaningrum, N., Sulistiyorini, L. (2015). Perbedaan Metode Buzz Group Discussion Dengan Ceramah Audiovisual Terhadap Tingkat Pendidikan Warga Binaan Tentang HIVIAIDS Di Lembaga Pemasyarakatan Klas IIA Kabupaten Jember. e-Jurnal Pustaka Kesehatan, 3(1).

Kaawoan, A. Y. A. (2012) . Hubungan Self Care Dan Depresi Dengan Kualitas Hidup Pasien Heart Failure Di RSUP Prof.DR.R.D Kandou Manado. Tesis, Program Pasca Sarjana Universitas Indonesia. Diunduh dari https://lib.ui.ac.id/ pada tanggal 21 Januari 2020.

Laksmi, I. A., Putra, P.W., Wiranata, I., K. (2019) . Studi Korelasi Antara BMI Dengan Mortalitas Pasien Gagal Antung Kongestif (studi kasus di RSUD Mangusada). GASTER, 17(1).

Nadya, N. M. S. (2020). Penerapan Pijat Punggung Terhadap Skor Kecemasan Pada Tn. T Dengan Congestive Heard Failure (CHF) di Ruang ICCU RSUD H. Hanafie Muara Bungo Tahun 2020 (Doctoral dissertation, Universitas Perintis Indonesia).

Noeraini, H., Eliyanti, Y., Amita, D. (2019). Effektivitas Metode Edukasi Brainstrorming Untuk
Meningkatkan Pemahaman Kasus Di Lahan PraktikPada Mahasiswa Profesi Ners. Jurnal Keperawatan Silampari, 2(2).

Nofalia, I. (2018). Pengaruh Metode Brainstorming, Buzz Group, And Simulation (Bbs) Terhadap Pengetahuan, Sikap, Dan Tindakan Merokok Pada Remaja. Skripsi, Universitas Airlangga.

Riset Kesehatan Dasar. (2013). Hasil Utama RIKESDAS 2018. Jakarta: Kementerian Kesehatan Republik Indonesia.

Rohimah, A. (2020). Efektivitas Metode Diskusi Buzz Group Terhadap Hasil Belajar Pesera Didik Pada Mata Pelajaran Matematika Kelas Iv Di Min 10 Bandar Lampung (Doctoral dissertation, UIN Raden Intan Lampung).

Ruwayda, R., \& Herawati, N. (2021). Perbandingan Metode Brainstorming dan Metode Buzz Group dalam Pemberian KIE Kesehatan Reproduksi di Posyandu Remaja Puskesmas Aur Duri Kota Jambi. Jurnal Akademika Baiturrahim Jambi, 10(1), 163-169.

WHO. 2018. Noncommunicable Disease. WHO: World Health Organization.

Winancy, Raksanagara, A. S., Fuadah, Y. (2015). Perbandingan Penerapan Metode Brainstorming Dan Buzz Group Terhadap Peningkatan Pengetahuan Suami Ibu Hamil Tentang Tanda Bahaya Kehamilan, Persalinan, Dan Nifas (Studi Kasus Di Bogor). The Southeast Asian Journal of Midwifery, 1(1). 